\title{
左腎動脈血行再建術後吻合部仮性動脈瘤の一治験例
}

\author{
島本健松田光彦添田健 \\ 青 田 正 樹洞 井 和 彦
}

\begin{abstract}
症例は 55 歳, 男性. 24 歳時に左腎動脈狭窄に対しテフロン代用血管による左腎動脈血行再建術を他 院にて施行された。当院における狭心症精査の際にとのグラフトを造影したところ, 径約 $4 \mathrm{~cm}$ の吻 合部仮性動脈瘤と診断され，再手術を施行した。瘤を切開し離開した初回手術吻合孔を閉鎖したの ち，あらかじめ腹部大動脈に端側吻合した人工血管に左腎動脈へのグラフトを端々吻合した，術後の 経過も順調であった。 日心外会誌 27 巻 4 号 : 245-248（1998）
\end{abstract}

Keywords：腎動脈血行再建術，吻合部仮性動脈瘤

\section{A Successful Surgical Repair of Anastomotic Aneurysm Complicated with Aorto-renal Bypass 31 Years after the Initial Operation}

Takeshi Shimamoto, Mitsuhiko Matsuda, Takeshi Soeda, Masaki Aota and Kazuhiko Doh-i (Department of Cardiovascular Surgery, Matsue Red Cross Hospital, Shimane, Japan)

A 55-year-old man was admitted with anterior chest pain. He had received aorto-renal bypass for left renal artery stenosis at the age of 24 . His coronary angiography with ergotamine malate provocation showed $99 \%$ stenosis in the left anterior descending artery and circumflex artery and abdominal aortography revealed an aneurysm with a diameter of $4 \mathrm{~cm}$ at the proximal site of the graft anastomosis. The patient was surgically treated with aneurysmectomy and PTFE grafting $(7 \mathrm{~mm})$ between abdominal aorta and the already-implanted graft to the left renal artery. His postoperative course was uneventful and no major complication such as renal failure were observed. Anastomotic aneurysm is a fairly common complication associated with arterial reconstruction which is most common in the common femoral artery. This is the first reported case of anastomotic aneurysm complicated by aorto-renal bypass. Jpn. J. Cardiovasc. Surg. 27 : 245-248 (1998)

吻合部仮性動脈瘤は動脈血行再建術後の合併症 の一つで，約 $1.7 \%$ の頻度で発症し，部位として は総大腿動脈が最も多い年, . 今回われわれは左 腎動脈血行再建術後の吻合部仮性動脈瘤を経験し たので，若干の文献的考察を加えて報告する。

\section{症例}

症例：55 歳, 男性.

主訴：前胸部痛。

既往歴：17 歳より高血圧. 23 歳時に左腎動脈 狭窄を指摘され，24 歳時に他院にて $8 \mathrm{~mm}$ のテ フロン代用血管を用いて左腎動脈血行再建術を施 行された。以後内服治療にて高血圧をコントロー ルされていた。

1997 年 9 月 16 日受付， 1998 年 2 月 12 日採用

松江赤十字病院心臓血管外科 $=690-0886$ 松江市母衣町 200

本論文の要旨は第 70 回日本循環器学会中国地方会総会 $(1997$

年 5 月広島) にて発表した。
現病歴：1996 年 9 月前胸部痛を自覚し心大血 管カテーテル造影検査を施行された。冠動脈造影 検査にて有意狭窄を認めなかったものの，エルゴ ノミン負荷テストで，心電図上 $\mathrm{V}_{1}-\mathrm{V}_{4}$ にて ST が上昇し，左前下行枝，回旋枝に $99 \%$ の狭窄を 認めた。腹部大動脈造影にて，左腎動脈へのグラ フトの中枢側の吻合部に径約 $4 \mathrm{~cm}$ の動脈瘤を認 め（図 1), 手術目的のため当科に入院となった。 入院時所見：身長 $172 \mathrm{~cm}$, 体重 $66.5 \mathrm{~kg}$ ，血 圧 $134 / 70 \mathrm{mmHg}$ ，脈拍 $65 /$ 分，整であった。 心 肺聴診上異常を認めなかった。腹部触診上，腫瘤 は触知せず，血管性雑音も聴取しなかった。大腿 動脈以下の脈拍は左右差なく良好に触知した。

検査所見：血液一般，血液生化学，凝固系，尿 検査では異常所見を認めなかった，胸腹部単純 $\mathrm{X}$ 線写真でも異常所見はなかった。

$\mathrm{CT}$ 検査：腹部大動脈に隣接して囊状の動脈瘤 

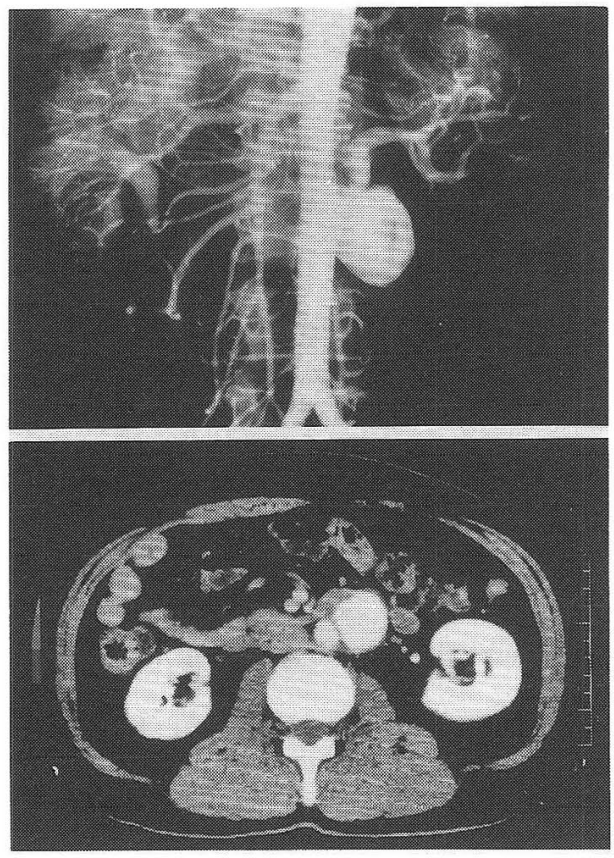

図 1 術前検查

上：腹部大動脈造影。径約 $4 \mathrm{~cm}$ の吻合部瘤が見られ る。下：腹部 CT 撮影。

を認めた（図 1)。

以上より左腎動脈血行再建術後の吻合部仮性動 脈瘤と診断し，1997 年1月 21 日手術を行った。

手術：腹部正中切開にて開腹した。下腸間膜動 脈起始部の頭側左寄りに囊状の動脈瘤を認めた (図 2)。下腸間膜動脈起始部遠位側の腹部大動脈 前面に side-biting clampをかけ径 $7 \mathrm{~mm}$ の PTFE 製人工血管を吻合した。瘤を切開したと ころ, 腹部大動脈に径 $7 \mathrm{~mm}$ のグラフト吻合孔 と，腹部大動脈とテフロン代用血管との吻合が離 開しているのが観察された。人工血管の変性は見 られなかった。3-0 Polyester 系にて初回手術吻 合孔を閉鎖した後， $4^{\circ} \mathrm{C} に$ 冷却したマンニトール 加乳酸リングル液 $200 \mathrm{ml}$ による腎保謢を行い, 左腎動脈へのテフロン代用血管グラフトと前述の PTFEグラフトをPTFE糸 (CV-6) の連続縫 合にて吻合した（図 2)。左腎の血流遮断時間は 80 分であった。術後の腎機能も問題なく, 術後 血管造影にて腹部大動脈から左腎への良好な血流 が確認された（図 3)。

大動脈瘤壁病理所見：血管壁は中膜組織はみら
れず硝子化の強い線維性組織から成っていた。内 膜にはコレステリン沈着・石灰化・血栓の付着が あり，外膜には vaso vasorum 周囲にリンパ球の 浸潤が見られた。

\section{考察}

吻合部仮性動脈瘤は血行再建術後の合併症の一 つであり，その発生率は約 $1.7 \%$ と報告されてい る1,2)。吻合部動脈溜の原因を特定するのは困難 であるが，動脈壁の脆弱性，高血圧，外圧等の機 械的なストレス，グラフトの欠陥，創傷治癒機転 上の感染などの合併症，不完全な縫合等が考えら れている 吻合部である大腿動脈，腸骨動脈，膝窩動脈，頸 動脈などの中小動脈に多く1)，グラフトの近位吻 合部である大動脈に瘤が見られた本症は稀な一例 であり ${ }^{4)}$ ，文献を調査した限りでは腎動脈血行再 建術後の吻合部動脈瘤の報告は本症例が最初であ る。治療法としては，吻合部瘤は破裂の危険性が 少なく径の拡大傾向や感染等がなければ経過観察

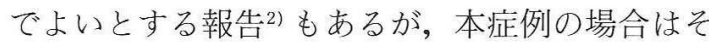
の径が $4 \mathrm{~cm}$ と大きく放置すれば拡大，破裂，腸 管瘦などの危険性もあることから外科的治療を行 つた。手術としては，あらかじめ腹部大動脈に新 しいグラフトを吻合し，初回手術吻合孔を直接閉 鎖した後前回手術にて左腎動脈に吻合されたテフ ロン代用血管と今回の手術であらかじめ腹部大動 脈に吻合したPTFE 製人工血管を端々吻合した (図 4-a)。この欠損孔が大きい場合にはパッチ閉 鎖（図 4-b)，腹部大動脈の性状が悪い場合には， その一部を人工血管に置換した後，左腎動脈への バイパス血管を吻合するのが適切であると考えら れる (図 4-c)。腎保護に関しては，血流遮断下 に腎動脈を再建する場合が多いが，中にはマンニ トールを経静脈的に投与するとする報告も見られ る ${ }^{5)}$. 本症例は再手術で周囲の組織との癒着が激 しく血行再建に長時間を要する可能性があると考 えられた。腎細胞代謝と虚血性の細胞浮腫を抑制 するため， $4^{\circ} \mathrm{C}$ に冷却した乳酸リンゲルとマンニ トールを 4：1に混合した液を間欠的に左腎へ注 入し腎保護を行った。その結果左腎の血行遮断時 間は 80 分に及んだものの，術後に腎機能低下は 


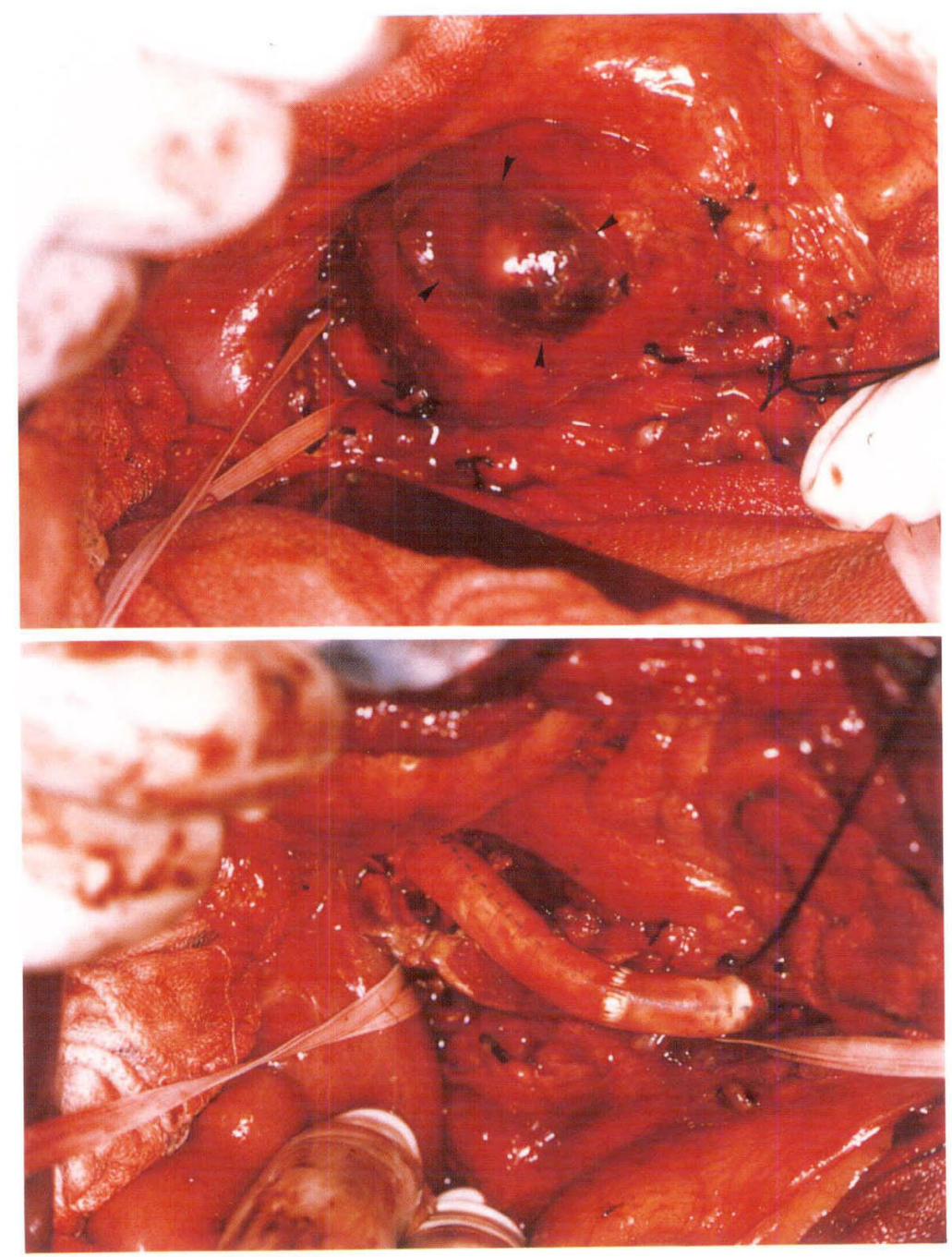

図 2 術中撮影

上：吻合部瘤. 下：PTFE graft $(7 \mathrm{~mm})$ による左腎動脈血行再建後.

見られなかった、今後，腎動脈再建に当たって血 行再建に長時間要すると予想される場合には十分 な腎保護に留意する必要がある。

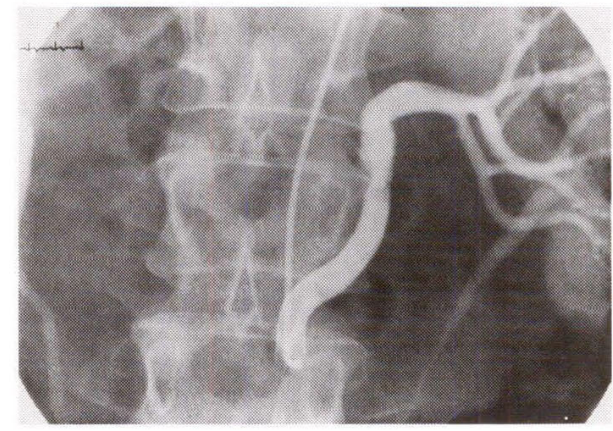

図 3 術後造影

今回新たに挿入したPTFEグラフトから前回手術時 に插入された人工血管を通じて左腎八良好な血行が 保たれている。 


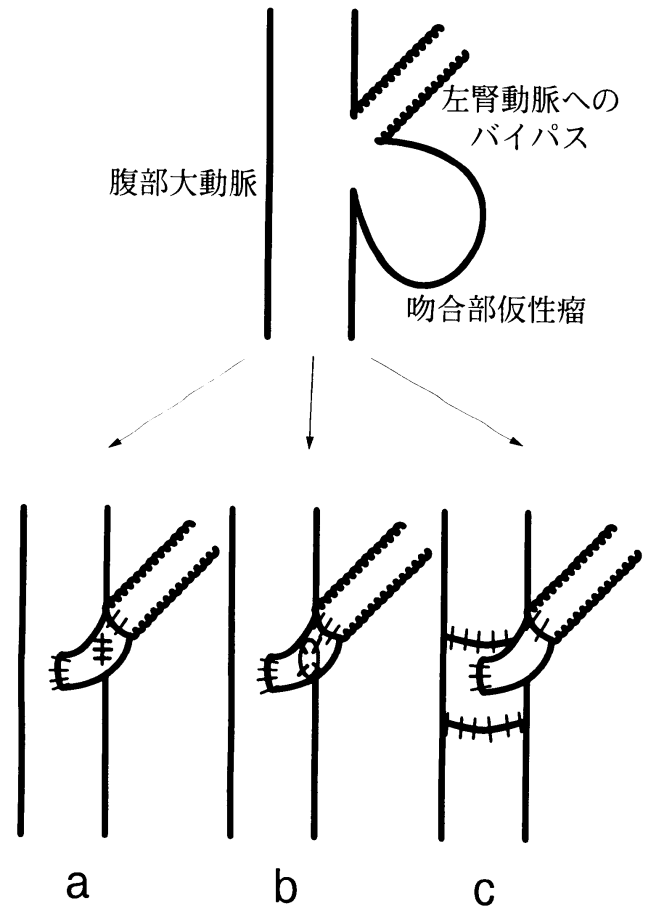

a b

C

\section{文献}

1) Szilagyi, D. E., Smith, R. F., Elliott, J. P. et al. : Anastomotic aneurysms after vascular reconstruction: Problems of incidence, etiology, and treatment. Surgery 78: 800-816, 1975.

2) Szilagyi, D. E. : Common femoral anastomotic aneurysms. Vascular Surgery, 4th ed., ed. by Haimovici, H., pp. 857-862, Blackwell Science Inc., Massachusetts, 1996.

3) Gaylis, H.: Pathogenesis of anastomotic aneurysms. Surgery 90: 509-515, 1981.

4) Jarstfer, B. S. and Rich, N. M. : Renal artery false aneurysm-an unusual complication of prosthetic patch angioplasty. Am. J. Surg. 132 : 657-659, 1976.

5) Ernst, C. B. and Chitwood, R. W. : Renal artery reconstruction. Vascular Surgery, 4th ed., ed. by Haimovici, H., pp. 1008-1027, Blackwell Science Inc., Massachusetts, 1996.

図 4 Suggested operative strategy 